\title{
Enlightening Diagnosis and Differential Diagnosis of Dental Fluorosis-A Hidden Entity in a Crowd
}

\author{
Deepika Patidar ${ }^{1}$ Suma Sogi ${ }^{2}$ Dinesh Chand Patida ${ }^{3}$
}

\section{Atul Sharma ${ }^{4}$ Mansi Jain ${ }^{2}$ Priyanka Prasad ${ }^{5}$}

\author{
Address for correspondence Dinesh Chand Patidar, MDS, \\ Department of Oral and Maxillofacial Surgery, College of \\ Dental Science and Hospital, Rau Indore, Madhya Pradesh, India \\ (e-mail: drdineshpatidar30@gmail.com).
}

\begin{abstract}
Keywords

- dental fluorosis

- diagnosis

- differential diagnosis

- discoloration

- opacities

Aim To provide diagnosis as well as differential diagnosis of dental fluorosis. Background Dental fluorosis is a developmental defect of enamel, due to consecutive exposures of tooth during the formative stage of development to the higher concentration of fluoride, resulting in enamel with lesser mineral content and enhanced porosity. Several epidemiological indices have been utilized for diagnosis and assessment of dental fluorosis on the basis of clinical appearance. Fluorosis of the deciduous teeth occurs less commonly and is milder than that of permanent teeth.

Highlights The diagnostic difficulties are usually associated between fluorotic and nonfluoride opacities. A complete history of the clinical condition, teeth affected with specific areas, pattern of lesion, color and its method of detection are the few important diagnostic criteria for differentiating dental fluorosis from nonfluoride discolorations of the teeth.

Conclusion This review article has enlightened the diagnosis and differential diagnosis of dental fluorosis among various nonfluoride tooth discolorations. A correct diagnosis results in an appropriate and early management of dental fluorosis and plays an important role in oral epidemiology and public health.
\end{abstract}

\section{Introduction}

Dental fluorosis is one the most frequent causes of intrinsic tooth discoloration. ${ }^{1}$ It can be defined as "hypomineralization of the enamel, caused by the excess of fluoride in the environment surrounding the enamel during tooth formation."2 It is a developmental defect of enamel, due to

published online March 18, 2021
DOI https://doi.org/

$10.1055 / \mathrm{s}-0041-1725218$

ISSN 2321-1482. consecutive exposures of tooth during the formative stage of development to the higher concentration of fluoride, resulting in enamel with lesser mineral content and enhanced porosity. A daily fluoride intake of 0.05 to $0.7 \mathrm{mg} \mathrm{F} / \mathrm{kg} /$ day or 1 parts per million ( $\mathrm{ppm}$ ) is the known recommended level. A daily intake of more than this safe level leads to an enhanced risk of dental fluorosis. ${ }^{3}$
C2021. Bhojia Dental College and Hospital affiliated to Himachal Pradesh University.

This is an open access article published by Thieme under the terms of the Creative Commons Attribution-NonDerivative-NonCommercial-License, permitting copying and reproduction so long as the original work is given appropriate credit. Contents may not be used for commercial purposes, or adapted, remixed, transformed or built upon. (https://creativecommons.org/licenses/by-nc-nd/4.0/).

Thieme Medical and Scientific Publishers Pvt. Ltd. A-12, 2nd Floor, Sector 2, Noida-201301 UP, India 
Fluorosis can be diagnosed through visual examination. ${ }^{4}$ Numerous indices have been developed to diagnose, qualify, and quantify the clinical features of dental fluorosis. ${ }^{2}$ Differentiation between fluorotic and nonfluorotic disturbances of tooth enamel is a prime necessity for evaluating an appropriate treatment plan. Dental fluorosis could be distinguished from other defects of the tooth enamel on the basis of enamel color, its distribution on the affected teeth, and the extent of unaffected enamel.

A dental surgeon should be able to differentially diagnose dental fluorosis among other similar nonfluoride tooth discolorations. Hence, this paper attempts to provide a review on diagnosis as well as differential diagnosis of dental fluorosis.

\section{Diagnosis of Dental Fluorosis}

Diagnosis of dental fluorosis is mainly through its appearance. ${ }^{5}$ The diagnosis can be confirmed by reviewing the patient's medical history, with consideration given to systemic fluoride use. ${ }^{4}$ The major known risk factors are high fluoride level in drinking water, infant milk formula reconstituted with fluoridated water, dentifrices and supplements. Knowledge of enamel fluoride content could assist in diagnosis of dental fluorosis. In normal enamel, the outer enamel contains much higher levels of fluoride, whereas decreasing level is seen in the inner enamel. Fluoride content of inner enamel is directly related to the availability of fluoride during the development of tooth, while the surface enamel is affected by posteruptive fluoride uptake. ${ }^{5,6}$

The diagnostic difficulties are usually associated with the assessment of mild dental fluorosis in primary teeth, owing to their thinner enamel and more whitish appearance than permanent teeth. Primary teeth reveal less dental fluorosis than their permanent successors. This is thought to be due to placental tissue performing as a barrier to fluoride in fetal blood, less fluoride consumption during the lactation period, or by smaller duration of enamel formation and maturation of deciduous teeth. An enhancement in the severity of dental fluorosis is observed from anterior to posterior teeth in both the dentition. The thickness of enamel verifies the severity of dental fluorosis. .7

It was observed that later in the life enamel is completed, the greater is the severity of dental fluorosis. Enamel formation of cosmetically important teeth like permanent incisors and canines is normally completed by 7 years of age; thus, concern about development of dental fluorosis lies mainly in the initial 7 years of life. ${ }^{5,7}$

\section{The Initial Signs of Fluoride Induced Enamel Changes Visible $\mathbf{A s}^{5,8}$}

1) Fine striae of accentuated perikymata evenly dispersed over the tooth surface and are simply viewed in tangential direction.

2) In more affected teeth, these fine lines turn broader and more prominent. With increase in severity, the irregular opaque areas merge until widespread areas appear chalky white.
3) Pitting may take place, either as tiny depressions, or as single or multiple, rounded holes representing a loss of outer most enamel surface.

4) In badly affected tooth, almost the complete enamel surface appears to be "corroded" and an extensive loss of enamel surface is seen.

Several epidemiological indices have been utilized for the diagnosis and assessment of dental fluorosis on the basis of clinical appearance. Dean in 1934 developed an index for determining the presence and severity of mottled enamel. ${ }^{9}$ Dean was concerned about cosmetic deviations of the teeth; hence, he examined dental fluorosis under natural conditions, that is, on wet surfaces. In contrast, Thylstrup and Fejerskov were interested in the exact association between $\mathrm{F}$ exposure and the entire range of clinical as well as histological categories of dental fluorosis. It consists of 10 scores intended to characterize the degree of dental fluorosis involving buccal/ lingual and occlusal surfaces. ${ }^{9-12}$ The tooth surface index of fluorosis was given by Horowitz et al. ${ }^{13}$ A separate score is provided for facial and lingual surface of anterior teeth and for occlusal, buccal and lingual surface of posterior teeth. It highlights cosmetic appearance by examining the teeth without drying them ${ }^{9,11}$ (- Tables $\mathbf{1}$ and $\mathbf{2}$ ). ${ }^{9-26}$

\section{Differential Diagnosis of Dental Fluorosis}

Differentiation between fluoride and nonfluoride disturbances of dental enamel is a valuable diagnostic step toward an oral epidemiology and public health concern. Several investigators have suggested descriptive indices for classifying other similar nonfluoride enamel opacities (- Table $\mathbf{1}$ ). However, endemic prevalence, history of more than optimal fluoride ingestion in drinking water during tooth development, and its bilateral symmetrical pattern are considered as important differentiating features for diagnosing dental fluorosis ( - Fig. 1$)^{6}$ ( - Tables 3-5). 5,9,27-32

Table 1 Various epidemiological indices for dental fluorosis ${ }^{9}$

\begin{tabular}{|l|l|l|}
\hline S.No. & Indices & Year \\
\hline 1. & DI, Modified DI & 1934,1942 \\
\hline 2. & Community index of fluorosis & 1946 \\
\hline 3. & Moller's index & 1965 \\
\hline 4. & TFI, modified criteria & 1978,1988 \\
\hline 5. & TSIF & 1984 \\
\hline 6. & Fluorosis risk index & 1990 \\
\hline 7. & CFAl & 1993 \\
\hline 8. & $\begin{array}{l}\text { Descriptive classification applied to quantify the } \\
\text { enamel opacity }\end{array}$ & \multicolumn{1}{|l|}{} \\
\hline & $\bullet$ Young's classification & 1973 \\
\hline & $\bullet$ Al Alousi et al & 1977 \\
\hline & $\bullet$ FDI index: DDE & 1979 \\
\hline & $\bullet$ Murray and Shaw & \\
\hline
\end{tabular}

Abbreviations: CFAl, chronological fluorosis assessment index; DDE, developmental defects of enamel; DI, Dean's index; FDI, Fédération Dentaire Internationale; TFI, Thylstrup-Fejerskov index; TSIF, tooth surface index of fluorosis. 
Table 2 Review of various studies using indices and newer methods for diagnosing dental fluorosis with their outcomes ${ }^{10-26}$

\begin{tabular}{|c|c|c|c|}
\hline Author & Year & $\begin{array}{l}\text { Indices/ } \\
\text { newer method }\end{array}$ & Outcomes \\
\hline $\begin{array}{l}\text { Thylstrup and } \\
\text { Fejerskov }\end{array}$ & 1978 & TFI & $\begin{array}{l}\text { TFI was valuable when biological effect of long-term exposure of young } \\
\text { individuals to } \mathrm{F}^{-} \text {is to be verified, whereas classical DI was not able to } \\
\text { differentiate between dental fluorosis with } 3.5,6.0 \text { and } 21.0 \mathrm{ppm} \mathrm{F}^{-} \text {in } \\
\text { drinking water }\end{array}$ \\
\hline Horowitz et a ${ }^{13}$ & 1984 & TSIF & $\begin{array}{l}\text { DI lacks sensitivity in areas with very high conc. of F- in water; however, } \\
\text { TSIF was sensitive enough for communities with different concentration } \\
\text { of F- levels and is easy to learn and less time consuming as well }\end{array}$ \\
\hline Granath et al ${ }^{14}$ & 1985 & $\mathrm{DI}$ and TFI & $\begin{array}{l}\text { Scoring given by DI was not statistically significant between tablet and } \\
\text { control group, whereas TF gave significant difference between these two } \\
\text { groups and thus recommended for epidemiological surveys }\end{array}$ \\
\hline Horowitz et al ${ }^{15}$ & 1986 & TSIF & $\begin{array}{l}\text { TSIF was able to distinguish between prevalence and severity of } \mathrm{F}^{-} \\
\text {in different group of communities with different conc. of } \mathrm{F}^{-} \text {in } \\
\text { drinking water }\end{array}$ \\
\hline Burger et a ${ }^{16}$ & 1987 & DI and TF & $\begin{array}{l}\text { The two scoring systems shown almost similar prevalence but varied in } \\
\text { the severity. TF is easier to use and will be selected for future studies }\end{array}$ \\
\hline Clark et al ${ }^{17}$ & 1993 & TSIF & $\begin{array}{l}\text { Evaluated the aesthetic concern of children and their parents for dental } \\
\text { fluorosis and found less children with aesthetic problems with TSIF } \\
\text { "score } 1, \text { " while children with TSIF "score } 2-6 \text { " were more concerned } \\
\text { about tooth color }\end{array}$ \\
\hline Mabelya et al ${ }^{10}$ & 1994 & $\mathrm{DI}$ and TF & $\begin{array}{l}\text { TFI was able to present more dental fluorosis than DI in communities } \\
\text { with low and moderate dental fluorosis; however, DI lacks accuracy to } \\
\text { differentiate within low fluorosis score }\end{array}$ \\
\hline Rozier et al ${ }^{11}$ & 1994 & DI, TFI and TSIF & $\begin{array}{l}\text { It was observed that TFI was more appropriate than other two indices for } \\
\text { clinical and analytic epidemiological studies }\end{array}$ \\
\hline Van Palenstein et al ${ }^{18}$ & 1997 & TFI & $\begin{array}{l}\text { In low-fluorosis communities, incisors and first molars are least affected; } \\
\text { In high-fluorosis communities, increasing TF values from anterior to pos- } \\
\text { terior teeth in both the arches, and proposed that later in the life enamel } \\
\text { is completed, greater is the severity of dental fluorosis }\end{array}$ \\
\hline Anya Vieira et al ${ }^{19}$ & 2005 & $\begin{array}{l}\text { VAS for dental } \\
\text { fluorosis and TFI }\end{array}$ & $\begin{array}{l}\text { Study showed better correlation between fluoride conc. and the VAS for } \\
\text { dental fluorosis than between F- conc. and the TFI. VAS can be valuable } \\
\text { in dental fluorosis }\end{array}$ \\
\hline Martins et $a^{20}$ & 2009 & $\begin{array}{l}\text { Standardized } \\
\text { digital photographic } \\
\text { method }\end{array}$ & $\begin{array}{l}\text { The photographic method offered a high specificity and positive pre- } \\
\text { dictive value, indicated its reproducibility and reliability for diagnosing } \\
\text { dental fluorosis }\end{array}$ \\
\hline Adelario et $\mathrm{al}^{21}$ & 2010 & Simplified TFI & $\begin{array}{l}\text { The simplified TFI proved appropriate for evaluating the prevalence of } \\
\text { dental fluorosis in regions with high concentration of fluoride in drinking } \\
\text { water/endemic fluorosis }\end{array}$ \\
\hline Mohamed et $\mathrm{al}^{22}$ & 2010 & DI and DDE & $\begin{array}{l}\text { Comparatively little concordance was observed between DDE and DI in } \\
\text { determining person prevalence of defects among children. DDE records } \\
\mathrm{F}^{-} \text {and non } \mathrm{F}^{-} \text {defects, yet is relatively complex and time consuming }\end{array}$ \\
\hline Pretty et al ${ }^{23}$ & 2012 & $\begin{array}{l}\text { A novel dual camera } \\
\text { imaging system. } \\
\text { DI and TFI }\end{array}$ & $\begin{array}{l}\text { The novel dual camera imaging system using both polarized white light } \\
\text { (PWL) and QLF imaging was suitable for determining enamel fluorosis in } \\
\text { an epidemiological setting }\end{array}$ \\
\hline Sudhir et a ${ }^{24}$ & 2012 & TFI & $\begin{array}{l}\text { The intraoral distribution of different degrees of dental fluorosis was } \\
\text { associated with the completion of primary enamel formation in high } \\
\text { fluoride communities with an exception of permanent first and second } \\
\text { molars }\end{array}$ \\
\hline Michael et al ${ }^{25}$ & 2012 & TFI and QLF & $\begin{array}{l}\text { Fluorescence imaging technique distinguished between fluoridated and } \\
\text { non-fluoridated population and is useful for the assessment of dental } \\
\text { fluorosis when used adjunctively with photographic scoring }\end{array}$ \\
\hline Sabokseir et al26 & 2016 & DI, TF and ECEL & $\begin{array}{l}\text { The frequently used measures of fluorosis appear to overscore fluorosis. } \\
\text { Use of ECEL grid method helps to differentiate between genuine fluorosis } \\
\text { and fluorosis-resembling defects }\end{array}$ \\
\hline
\end{tabular}

Abbreviations: DDE, developmental defects of enamel; DI, Dean's index; EDEL, early childhood events life; QLF, quantitative light-induced fluorescence; TFI, Thylstrup-Fejerskov index; TSIF, tooth surface index of fluorosis; VAS, visual analog scale. 


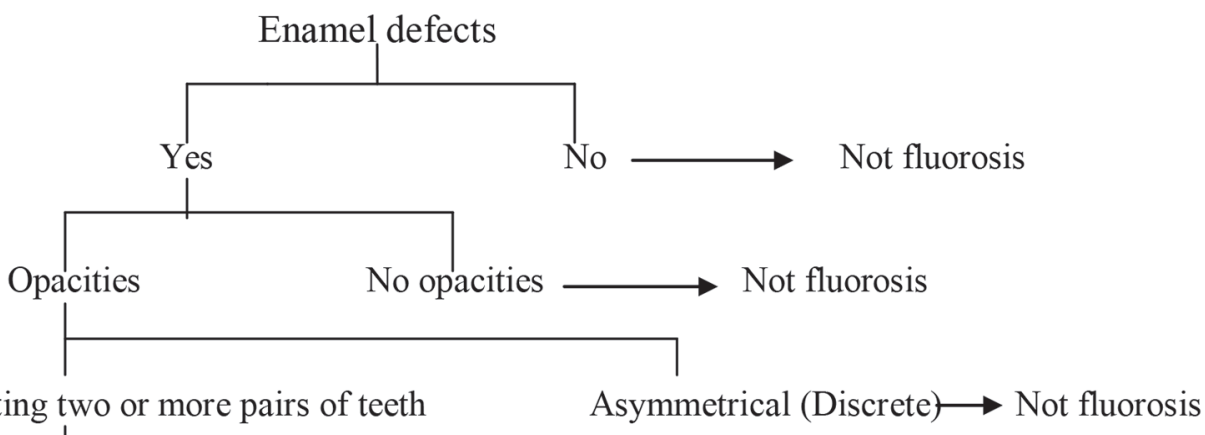

Symmetrical, affecting two or more pairs of teeth

Asymmetrical (Discrete) $\longrightarrow$ Not fluorosis

Condition- non endemic<smiles>CC=CC</smiles>

Check for atypical exposure to fluorides

Low fluoride (Water)

Condition- endemic

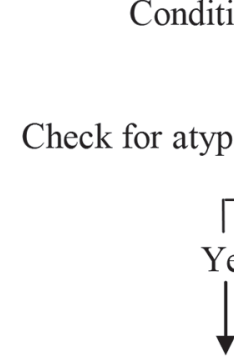

Fluorosis

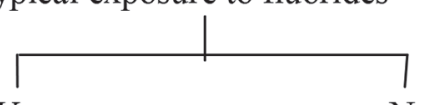

Yes

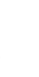

No

Yes<smiles>CCC</smiles>

Check medical history

Check for fluoride in tissue

Evidence favours
High fluoride (Water)

Yes $\longrightarrow$ Fluorosis

\section{Fluorosis Not fluorosis Not proven}

Fig. 1 Flow chart showing the sequence recommended for differential diagnosis of dental fluorosis.

Table 3 Difference between dental fluorosis and nonfluoride developmental defects and opacities,27-29

\begin{tabular}{|l|l|l|l|l|l|}
\hline Features & Dental fluorosis & $\begin{array}{l}\text { Amelogenesis } \\
\text { imperfecta }\end{array}$ & Enamel hypoplasia & $\begin{array}{l}\text { Dentinogenesis } \\
\text { imperfecta }\end{array}$ & $\begin{array}{l}\text { Molar-incisor } \\
\text { hypomineralization }\end{array}$ \\
\hline Area affected & $\begin{array}{l}\text { The entire tooth sur- } \\
\text { faces often enhanced } \\
\text { or near tips of cusps/ } \\
\text { incisal edges }\end{array}$ & $\begin{array}{l}\text { Centered in smooth } \\
\text { surface of limited } \\
\text { extent } \\
\text { Hypoplastic- } \\
\text { buccal surface } \\
\text { Hypomaturation- } \\
\text { incisal or occlusal }\end{array}$ & $\begin{array}{l}\text { Localized to the center of } \\
\text { the smooth surface }\end{array}$ & $\begin{array}{l}\text { The entire tooth } \\
\text { surfaces }\end{array}$ & $\begin{array}{l}\text { Loss of initially formed } \\
\text { surface enamel after } \\
\text { tooth eruption }\end{array}$ \\
\hline Lesion & $\begin{array}{l}\text { Show a horizontal } \\
\text { striated pattern across } \\
\text { the tooth. Bilateral } \\
\text { symmetrical } \\
\text { Qualitative defect- } \\
\text { enamel has normal } \\
\text { thickness, but changes } \\
\text { in its translucency }\end{array}$ & $\begin{array}{l}\text { Show vertical bands } \\
\text { of white, opaque or } \\
\text { translucent enamel } \\
\text { surface and are } \\
\text { round and oval in } \\
\text { appearance. } \\
\text { Qualitative/ } \\
\text { quantitative }\end{array}$ & $\begin{array}{l}\text { Round and oval in } \\
\text { appearance. Occurs in } \\
\text { the form of pits, grooves } \\
\text { Quantitative defect- } \\
\text { enamel is of reduced } \\
\text { thickness }\end{array}$ & $\begin{array}{l}\text { Affected teeth show } \\
\text { distinct translu- } \\
\text { cency and enamel } \\
\text { frequently separates } \\
\text { from underlying } \\
\text { defected dentin }\end{array}$ & $\begin{array}{l}\text { Soft, porous, brittle } \\
\text { enamel resembling } \\
\text { discolored chalk or old } \\
\text { Dutch cheese } \\
\text { Qualitative defect- } \\
\text { enamel is of normal } \\
\text { thickness with a } \\
\text { smooth surface }\end{array}$ \\
\hline $\begin{array}{l}\text { High-fluoride level } \\
\text { in drinking water in } \\
\text { a community with } \\
\text { water fluoridation, } \\
\text { history of fluoride } \\
\text { supplementation }\end{array}$ & $\begin{array}{l}\text { Hereditary/familial } \\
\text { pattern }\end{array}$ & $\begin{array}{l}\text { If injury occurs during } \\
\text { formative stage of } \\
\text { enamel development } \\
\text { Incomplete or defective } \\
\text { formation of the organic } \\
\text { enamel matrix of teeth }\end{array}$ & $\begin{array}{l}\text { Hereditary/familial } \\
\text { pattern. Autosomal } \\
\text { dominant condition }\end{array}$ & $\begin{array}{l}\text { Systemic alteration } \\
\text { during maturation } \\
\text { phase of enamel / } \\
\text { idiopathic enamel } \\
\text { defect with unknown } \\
\text { etiology }\end{array}$ \\
\hline
\end{tabular}


Table 3 (Continued)

\begin{tabular}{|c|c|c|c|c|c|}
\hline Features & Dental fluorosis & $\begin{array}{l}\text { Amelogenesis } \\
\text { imperfecta }\end{array}$ & Enamel hypoplasia & $\begin{array}{l}\text { Dentinogenesis } \\
\text { imperfecta }\end{array}$ & $\begin{array}{l}\text { Molar-incisor } \\
\text { hypomineralization }\end{array}$ \\
\hline Demarcation & Diffuse distribution & $\begin{array}{l}\text { Clearly differenti- } \\
\text { ated from adjacent } \\
\text { normal enamel. }\end{array}$ & $\begin{array}{l}\text { Clearly differentiated } \\
\text { from adjacent normal } \\
\text { enamel }\end{array}$ & Clearly differentiated & $\begin{array}{l}\text { Sharp demarcation } \\
\text { between the affected } \\
\text { and sound enamel }\end{array}$ \\
\hline Color & $\begin{array}{l}\text { Slightly more opaque } \\
\text { than normal enamel; } \\
\text { "paper white." Incisal } \\
\text { edges, tips of cusps } \\
\text { may have frosted } \\
\text { appearance } \\
\text { Does not show stain } \\
\text { at the time of tooth } \\
\text { eruption }\end{array}$ & $\begin{array}{l}\text { Usually pigmented } \\
\text { at the time of erup- } \\
\text { tion; often creamy } \\
\text { yellow to dark } \\
\text { reddish orange }\end{array}$ & Brownish discoloration & $\begin{array}{l}\text { Bluish to amber } \\
\text { brownish }\end{array}$ & $\begin{array}{l}\text { White to yellow or } \\
\text { brown in color }\end{array}$ \\
\hline $\begin{array}{l}\text { Teeth } \\
\text { affected }\end{array}$ & $\begin{array}{l}\text { Teeth that calcify } \\
\text { slowly (cuspids, bicus- } \\
\text { pids, second and third } \\
\text { molars) } \\
\text { Always on homologous } \\
\text { teeth } \\
\text { Extremely rare on } \\
\text { deciduous teeth }\end{array}$ & $\begin{array}{l}\text { Any tooth may be } \\
\text { affected } \\
\text { Frequent on labial } \\
\text { surface of lower } \\
\text { incisors } \\
\text { Common in decidu- } \\
\text { ous teeth }\end{array}$ & $\begin{array}{l}\text { Hereditary type-Both } \\
\text { the dentitions are } \\
\text { affected } \\
\text { Environmental type-- } \\
\text { Either dentition is } \\
\text { involved } \\
\text { Hutchinson's incisor and } \\
\text { mulberry molars are seen } \\
\text { (congenital syphilis). } \\
\text { Incisors and Premolars } \\
\text { (Turner's hypoplasia) }\end{array}$ & $\begin{array}{l}\text { Both the denti- } \\
\text { tions are involved } \\
\text { Deciduous teeth are } \\
\text { more affected } \\
\text { followed by perma- } \\
\text { nent incisors, first, } \\
\text { second and third } \\
\text { molars are least } \\
\text { affected }\end{array}$ & $\begin{array}{l}\text { Both the dentitions are } \\
\text { involved } \\
\text { Usually affects } \\
\text { permanent molars } \\
\text { and incisors }\end{array}$ \\
\hline Detection & $\begin{array}{l}\text { Often invisible under } \\
\text { strong light; easily } \\
\text { detected by line of } \\
\text { sight tangential to } \\
\text { tooth crown }\end{array}$ & $\begin{array}{l}\text { Line of sight per- } \\
\text { pendicular to tooth } \\
\text { surface under strong } \\
\text { light }\end{array}$ & Translucent or opaque & $\begin{array}{l}\text { Affected teeth show } \\
\text { distinct translucency }\end{array}$ & $\begin{array}{l}\text { Alterations in the } \\
\text { translucency of the } \\
\text { enamel }\end{array}$ \\
\hline
\end{tabular}

Table 4 Difference between dental fluorosis and other tooth discoloration of systemic origin ${ }^{9,27,30,31}$

\begin{tabular}{|c|c|c|c|c|c|c|c|}
\hline Features & Dental fluorosis & $\begin{array}{l}\text { Tetracycline } \\
\text { staining }\end{array}$ & $\begin{array}{l}\text { Pulpal } \\
\text { hemorrhage }\end{array}$ & $\begin{array}{l}\text { Internal } \\
\text { resorption }\end{array}$ & \begin{tabular}{|l|} 
Congenital \\
erythropoietic \\
porphyria
\end{tabular} & $\begin{array}{l}\text { Congenital } \\
\text { hyperbiliru- } \\
\text { binemia and } \\
\text { eythroblasto- } \\
\text { sis fetalis }\end{array}$ & Alkaptonuria \\
\hline $\begin{array}{l}\text { Area } \\
\text { affected }\end{array}$ & $\begin{array}{l}\text { The entire tooth } \\
\text { surfaces or near } \\
\text { tips of cusps/ } \\
\text { incisal edges }\end{array}$ & $\begin{array}{l}\text { The entire tooth } \\
\text { surfaces }\end{array}$ & $\begin{array}{l}\text { The entire tooth } \\
\text { surfaces. Anterior } \\
\text { teeth are more } \\
\text { prone }\end{array}$ & $\begin{array}{l}\text { The entire tooth } \\
\text { surfaces }\end{array}$ & $\begin{array}{l}\text { The entire } \\
\text { tooth surfaces }\end{array}$ & $\begin{array}{l}\text { The entire } \\
\text { tooth surfaces }\end{array}$ & $\begin{array}{l}\text { The entire } \\
\text { tooth surfaces }\end{array}$ \\
\hline Color & $\begin{array}{l}\text { Slightly more } \\
\text { opaque than } \\
\text { normal enamel; } \\
\text { "paper white" to } \\
\text { yellowish brown } \\
\text { in severe cases }\end{array}$ & $\begin{array}{l}\text { Bright yellow to } \\
\text { dark brown }\end{array}$ & Bluish black & $\begin{array}{l}\text { Crown display a } \\
\text { pink discoloration } \\
\text { (pink tooth of } \\
\text { Mummery) }\end{array}$ & $\begin{array}{l}\text { A marked } \\
\text { red brown } \\
\text { discoloration }\end{array}$ & $\begin{array}{l}\text { Green } \\
\text { discoloration }\end{array}$ & $\begin{array}{l}\text { Blue black } \\
\text { discoloration }\end{array}$ \\
\hline History & $\begin{array}{l}\text { High fluoride } \\
\text { level in drinking } \\
\text { water }\end{array}$ & Past drug history & $\begin{array}{l}\text { History of } \\
\text { trauma }\end{array}$ & $\begin{array}{l}\text { Pulpal inflam- } \\
\text { mation is usually } \\
\text { caused by bacterial } \\
\text { invasion }\end{array}$ & \begin{tabular}{|l|} 
Medical history. \\
An autoso- \\
mal recessive \\
disorder of \\
porphyrin \\
metabolism
\end{tabular} & Medical history & $\begin{array}{l}\text { Medical } \\
\text { history. } \\
\text { An autosomal } \\
\text { recessive } \\
\text { metabolic } \\
\text { disorder }\end{array}$ \\
\hline Mechanism & \begin{tabular}{|l|} 
Successive \\
exposures to high \\
concentration of \\
fluoride during \\
the formative \\
stage of tooth \\
development
\end{tabular} & $\begin{array}{l}\text { Tetracycline and } \\
\text { its homologous } \\
\text { form complexes } \\
\text { with calcium ions } \\
\text { on the surface of } \\
\text { hydroxyapatite } \\
\text { crystals within } \\
\text { bone and dental } \\
\text { tissues }\end{array}$ & $\begin{array}{l}\text { Hemolysis of } \\
\text { the red blood } \\
\text { cells releases the } \\
\text { hem group to } \\
\text { combine with } \\
\text { the putrefying } \\
\text { pulpal tissue to } \\
\text { form black iron } \\
\text { sulphide }\end{array}$ & $\begin{array}{l}\text { Vascular resorp- } \\
\text { tive process } \\
\text { approaches the } \\
\text { surface of the } \\
\text { crown. } \\
\text { Resorbed dentin } \\
\text { is replaced by } \\
\text { inflamed granula- } \\
\text { tion tissue }\end{array}$ & $\begin{array}{l}\text { Increased } \\
\text { synthesis and } \\
\text { excretion of } \\
\text { porphyrins }\end{array}$ & $\begin{array}{l}\text { Deposition of } \\
\text { biliverdin (the } \\
\text { breakdown } \\
\text { product of the } \\
\text { bilirubin) and } \\
\text { may vary from } \\
\text { yellow to green }\end{array}$ & $\begin{array}{l}\text { Defect in } \\
\text { the enzyme } \\
\text { "homogenti- } \\
\text { sate oxidase," } \\
\text { homogenti- } \\
\text { sate accumu- } \\
\text { lates in tissues } \\
\text { and blood }\end{array}$ \\
\hline
\end{tabular}


Table 4 (Continued)

\begin{tabular}{|c|c|c|c|c|c|c|c|}
\hline Features & Dental fluorosis & $\begin{array}{l}\text { Tetracycline } \\
\text { staining }\end{array}$ & $\begin{array}{l}\text { Pulpal } \\
\text { hemorrhage }\end{array}$ & $\begin{array}{l}\text { Internal } \\
\text { resorption }\end{array}$ & $\begin{array}{l}\text { Congenital } \\
\text { erythropoietic } \\
\text { porphyria }\end{array}$ & $\begin{array}{l}\text { Congenital } \\
\text { hyperbiliru- } \\
\text { binemia and } \\
\text { eythroblasto- } \\
\text { sis fetalis }\end{array}$ & Alkaptonuria \\
\hline $\begin{array}{l}\text { Critical } \\
\text { time } \\
\text { period and } \\
\text { the teeth } \\
\text { involved }\end{array}$ & $\begin{array}{l}\text { Teeth that calcify } \\
\text { slowly (cus- } \\
\text { pids, bicuspids, } \\
\text { second and third } \\
\text { molars). Always } \\
\text { on homologous } \\
\text { teeth. Extremely } \\
\text { rare on decidu- } \\
\text { ous teeth }\end{array}$ & \begin{tabular}{|l|} 
Both the denti- \\
tions are involved. \\
Avoided during \\
pregnancy and in \\
children up to 8 \\
years of age
\end{tabular} & $\begin{array}{l}\text { Both the denti- } \\
\text { tions are involved }\end{array}$ & Both the dentitions & \begin{tabular}{|l|} 
Both the \\
dentitions are \\
involved. \\
In deciduous \\
teeth porphyrin \\
is present in \\
both enamel \\
and dentin \\
while in per- \\
manent teeth \\
only dentin is \\
affected \\
\end{tabular} & $\begin{array}{l}\text { Mostly decid- } \\
\text { uous teeth are } \\
\text { affected during } \\
\text { the neona- } \\
\text { tal period } \\
\text { Occasionally, } \\
\text { the cusps of } \\
\text { the permanent } \\
\text { first molar may } \\
\text { be affected }\end{array}$ & $\begin{array}{l}\text { Both the } \\
\text { dentitions }\end{array}$ \\
\hline Detection & $\begin{array}{l}\text { Often invisible } \\
\text { under strong } \\
\text { light; most easily } \\
\text { detected by line } \\
\text { of sight tan- } \\
\text { gential to tooth } \\
\text { crown }\end{array}$ & $\begin{array}{l}\text { a bright yellow flu- } \\
\text { orescence under } \\
\text { UV light }\end{array}$ & $\begin{array}{l}\text { Visible } \\
\text { bluish black } \\
\text { discoloration. }\end{array}$ & \begin{tabular}{|l|} 
Visible pink \\
discoloration. On \\
radiograph, a well \\
circumscribed radi- \\
olucent enlarge- \\
ment of the pulp \\
chamber is seen
\end{tabular} & $\begin{array}{l}\text { A red fluores- } \\
\text { cence when } \\
\text { exposed to a } \\
\text { Wood's UV } \\
\text { light }\end{array}$ & $\begin{array}{l}\text { Sharp dividing } \\
\text { line, sepa- } \\
\text { rating green } \\
\text { portions from } \\
\text { normal colored } \\
\text { portions }\end{array}$ & $\begin{array}{l}\text { Bluish black } \\
\text { discoloration }\end{array}$ \\
\hline
\end{tabular}

Table 5 Difference between dental fluorosis and dental caries ${ }^{5,9,32}$

\begin{tabular}{|c|c|c|c|}
\hline Features & Dental fluorosis & White spot lesion (incipient caries) & Rampant caries \\
\hline Area affected & $\begin{array}{l}\text { The entire tooth surfaces or } \\
\text { near tips of cusps/incisal edges }\end{array}$ & $\begin{array}{l}\text { Smooth surfaces near the cervical mar- } \\
\text { gin or contact area at proximal surface }\end{array}$ & Entire tooth surfaces often involved \\
\hline History & $\begin{array}{l}\text { High fluoride level in drinking } \\
\text { water or any history of fluoride } \\
\text { supplementation }\end{array}$ & $\begin{array}{l}\text { Multifactorial (diet, oral hygiene, etc.) } \\
\text { Posteruptive etiology }\end{array}$ & $\begin{array}{l}\text { Multifactorial (diet, oral hygiene) } \\
\text { Improper feeding practice }\end{array}$ \\
\hline Mechanism & $\begin{array}{l}\text { Successive exposures to high } \\
\text { concentration of fluoride } \\
\text { during the formative stage of } \\
\text { tooth development }\end{array}$ & $\begin{array}{l}\text { Change in tooth enamel due to loss of } \\
\text { the structure in the oral environment/ } \\
\text { demineralization of tooth enamel }\end{array}$ & $\begin{array}{l}\text { Demineralization of tooth enamel } \\
\text { and progression of lesion to dentin } \\
\text { and even pulp }\end{array}$ \\
\hline Lesion & $\begin{array}{l}\text { Show a horizontal striated } \\
\text { pattern across the tooth. } \\
\text { Bilaterally symmetrical }\end{array}$ & $\begin{array}{l}\text { The subsurface porosity caused by } \\
\text { demineralization gives a milky white } \\
\text { appearance }\end{array}$ & $\begin{array}{l}\text { Single tooth or even bilateral teeth } \\
\text { involvement }\end{array}$ \\
\hline Demarcation & $\begin{array}{l}\text { Diffuse distribution over the } \\
\text { surface of varying intensity }\end{array}$ & Visible on drying the tooth surface & $\begin{array}{l}\text { Visible cavitated brown/black } \\
\text { lesions. }\end{array}$ \\
\hline Teeth involved & $\begin{array}{l}\text { Teeth that calcify slowly } \\
\text { (cuspids, bicuspids, } \\
\text { second and third molars). } \\
\text { The mandibular incisors are } \\
\text { least affected. Always on } \\
\text { homologous teeth. Extremely } \\
\text { rare on deciduous teeth }\end{array}$ & $\begin{array}{l}\text { Any tooth may be affected depending } \\
\text { on the local attack of acid } \\
\text { Both the dentitions are involved }\end{array}$ & $\begin{array}{l}\text { Proximal surface of mandibular } \\
\text { anterior teeth which are immune to } \\
\text { decay are also involved } \\
\text { Both the dentitions are involved }\end{array}$ \\
\hline Detection & $\begin{array}{l}\text { Often invisible under strong } \\
\text { light; detected by line of sight } \\
\text { tangential to tooth crown }\end{array}$ & $\begin{array}{l}\text { Seen under fiberoptic light at an angle to } \\
\text { the tooth surface }\end{array}$ & $\begin{array}{l}\text { Visible cavitated brown /black } \\
\text { lesions }\end{array}$ \\
\hline Color & $\begin{array}{l}\text { Slightly more opaque than } \\
\text { normal enamel; "paper white," } \\
\text { incisal edges, tips of cusps } \\
\text { may have frosted appearance } \\
\text { No staining at the time of } \\
\text { tooth eruption }\end{array}$ & $\begin{array}{l}\text { Usually pigmented at the time of } \\
\text { eruption; often creamy yellow to dark } \\
\text { reddish orange }\end{array}$ & $\begin{array}{l}\text { Dark brown to blackish in } \\
\text { appearance }\end{array}$ \\
\hline
\end{tabular}




\section{Discussion}

The adequate diagnosis of dental fluorosis necessitates examination of dry, clean tooth surfaces in the presence of good source of light. Its clinical appearance varies in intensity from hardly evident white striations to confluent pitting and staining. The fluorosed enamel is not discolored on eruption into the mouth; the discoloration develops eventually due to diffusion of exogenous ions into the porous enamel. It was observed that teeth develop later in the life are more susceptible for dental fluorosis.,7,15 Thylstrup and Thylstrup and Fejerskov noted a progressive increase in the severity from anterior to posterior teeth in maxilla as well as mandible., ${ }^{72}$ Various indices have been employed in surveys to measure the presence and severity of enamel fluorosis. Dean's index (DI) due to its simplicity and extensive use over the years and historical importance provides a standard of comparison for other indices. However, it is unable to provide adequate information on the distribution of dental fluorosis within the dentition and particularly with its lowest score-the questionable score. Higher Dl scores are not sensitive enough to differentiate between the severe forms of dental fluorosis, while Thylstrup and Fejerskov index (TFI) was capable to assess dental fluorosis in areas with different levels of fluoride in drinking water (3.5, 6.0, and $21.0 \mathrm{ppm}$ ). ${ }^{9-12}$ Owing to drying of tooth before scoring and appropriateness of TFI to identify very mild type of dental fluorosis, a higher prevalence of dental fluorosis was noted with TFI than with DI in the low and moderate fluorosis areas. ${ }^{9-12}$ Moreover, it has been noted that tooth surface index of fluorosis (TSIF) diagnostic criteria are clearer and valuable in analytic studies. ${ }^{10-11,15}$

Numerous investigators have found DI to be less accurate and sensitive as compared with TFI and TSIF, as shown in - Table 2, along with few newer diagnosing methods for dental fluorosis. ${ }^{10-14}$ The acceptance of these indices depends on the ability of the examiner to discriminate fluoride-induced variations in the tooth enamel from those nonfluoride induced. Excess fluoride ingestion is commonly blamed for mottling; however, opacities and pigmentation of enamel can be due to several other causes and present clinical problems to the dental practitioner. ${ }^{11,33} \mathrm{~A}$ complete history of the clinical condition, distribution on the affected tooth or within the dentition, pattern of lesion, color and its method of detection are the few important diagnostic criteria for differentiating dental fluorosis from nonfluoride discolorations of the teeth (-Tables 3-5 and -Fig. 1).

\section{Conclusion}

Dental fluorosis can be prevented and treated. Dental practitioners should not only have appropriate knowledge regarding etiology, occurrence and clinical appearance of dental fluorosis but also be able to differentiate it from other nonfluoride resembling defects.

\section{Clinical Significance}

This review article enlightened the detail clinical presentation of various fluoride and other resembling tooth discolorations. A correct diagnosis results in an appropriate management of dental fluorosis and plays an important role in public health concern.

\section{Conflict of Interest}

None declared.

\section{Acknowledgment}

The authors wish to thank Dr. G.M. Sogi, Principal Professor \& Head, Department of Public Health Dentistry, Maharishi Markandeshwar College of Dental Sciences and Research, Ambala, Haryana, India.

\section{References}

1 Sinha S, Vorse KK, Noorani H, Kumaraswamy SP, Varma S, Surappaneni H. Microabrasion using 18\% hydrochloric acid and $37 \%$ phosphoric acid in various degrees of fluorosis - an in vivo comparision. Eur J Esthet Dent 2013;8(3):454-465

2 Soto-Rojas AE, Martínez-Mier EA, Ureña-Cirett J, Jackson RD, Stookey GK. Development of a standardisation device for photographic assessment of dental fluorosis in field studies. Oral Health Prev Dent 2008;6(1):29-36

3 Alvarez JA. Dental fluorosis: exposure, prevention and management. J Clin Exp Dent 2009;1:14-18

4 Ritter AV. Ritter. Talking with patients. Dental Fluorosis. J Esthet Restor Dent 2005;17:326-327

5 Fejerskov O, Ekstrand J, Burt BA, Fluoride in Dentistry. 2nd ed. Copenhagen: Munksgaard; 1996 42-46,132-34

6 Cutress TW, Suckling GW. Differential diagnosis of dental fluorosis. J Dent Res 1990;69(Spec No) :714-720

7 Thylstrup A. Distribution of dental fluorosis in the primary dentition. Community Dent Oral Epidemiol 1978;6(6):329-337

8 Fejerskov O, Thylstrup A, Larsen MJ. Clinical and structural features and possible pathogenic mechanisms of dental fluorosis. Scand J Dent Res 1977;85(7):510-534

9 Murray JJ, Rugg-Gunn, AJ, Fluorides in Caries Prevention. 3rd ed. Mumbai: Varghese Publishing; 1999 262-65

10 Mabelya L, van 't Hof MA, König KG, van Palenstein Helderman WH. Comparison of two indices of dental fluorosis in low, moderate and high fluorosis Tanzanian populations. Community Dent Oral Epidemiol 1994;22(6):415-420

11 Rozier RG. Epidemiologic indices for measuring the clinical manifestations of dental fluorosis: overview and critique. Adv Dent Res 1994;8(1):39-55

12 Thylstrup A, Fejerskov O. Clinical appearance of dental fluorosis in permanent teeth in relation to histologic changes. Community Dent Oral Epidemiol 1978;6(6):315-328

13 Horowitz HS, Driscoll WS, Meyers RJ, Heifetz SB, Kingman A. A new method for assessing the prevalence of dental fluorosis-the Tooth Surface Index of Fluorosis. J Am Dent Assoc 1984;109(1):37-41

14 Granath L, Widenheim J, Birkhed D. Diagnosis of mild enamel fluorosis in permanent maxillary incisors using two scoring systems. Community Dent Oral Epidemiol 1985;13(5):273-276

15 Horowitz HS. Indexes for measuring dental fluorosis. J Public Health Dent 1986;46(4):179-183 
16 Burger P, Cleaton-Jones P, du Plessis J, de Vries J. Comparison of two fluorosis indices in the primary dentition of Tswana children. Community Dent Oral Epidemiol 1987;15(2):95-97

17 Clark DC, Hann HJ, Williamson MF, Berkowitz J. Aesthetic concerns of children and parents in relation to different classifications of the Tooth Surface Index of Fluorosis. Community Dent Oral Epidemiol 1993;21(6):360-364

18 van Palenstein Helderman WH, Mabelya L, van't Hof MA, König KG. Two types of intraoral distribution of fluorotic enamel. Community Dent Oral Epidemiol 1997;25(3):251-255

19 Anya, Vieira PGF, Lawrence, HP, Limeback, H, Sampaio, FC, Grynpas, M. A visual analogue scale for measuring dental fluorosis severity. J Am Dent Assoc 2005;136:895-901

20 Martins CC, Chalub L, Lima-Arsati YB, Pordeus IA, Paiva SM. Agreement in the diagnosis of dental fluorosis in central incisors performed by a standardized photographic method and clinical examination. Cad Saude Publica 2009;25(5):1017-1024

21 Adelário AK, Vilas-Novas LF, Castilho LS, Vargas AM, Ferreira EF, Abreu MH. Accuracy of the simplified Thylstrup \& Fejerskov index in rural communities with endemic fluorosis. Int J Environ Res Public Health 2010;7(3):927-937

22 Mohamed AR, Thomson WM, Mackay TD. An epidemiological comparison of Dean's index and the Developmental Defects of Enamel (DDE) index. J Public Health Dent 2010;70(4):344-347

23 Pretty IA, McGrady M, Zakian C, et al. Quantitative light fluorescence (QLF) and polarized white light (PWL) assessments of dental fluorosis in an epidemiological setting. BMC Public Health 2012;12:366
24 Sudhir KM, Suresh S, Prashant GM, Reddy VV, Shafiulla M, Chandu GN. Distribution patterns of enamel fluorosis in permanent dentition. Oral Health Prev Dent 2012;10(2):167-174

25 McGrady MG, Ellwood RP, Taylor A, et al. Evaluating the use of fluorescent imaging for the quantification of dental fluorosis. BMC Oral Health 2012;12:47

26 Sabokseir A, Golkari A, Sheiham A. Distinguishing between enamel fluorosis and other enamel defects in permanent teeth of children. PeerJ 2016;4:e1745

27 Neville, B, Damm, DD, Allen, C, Chi, A, Oral and Maxillofacial Pathology. 1st South Asia ed. New Delhi: Elsevier; 2015 49-105

28 Shafer H, Levy: Textbook of Oral Pathology. 7th ed. New Delhi: Elsevier; 2012 50-58

29 Allazzam SM, Alaki SM, El Meligy OA. Molar incisor hypomineralization, prevalence, and etiology. Int J Dent 2014;2014: 234508

30 Marin PD, Bartold PM, Heithersay GS. Tooth discoloration by blood: an in vitro histochemical study. Endod Dent Traumatol 1997;13(3):132-138

31 Satyanarayan U, Chakrapani U, Biochemistry. 4th ed. New Delhi: Elsevier; 2013 352-53

32 Tandon S, Textbook of Pedodontics. Vol. 1. 3rd ed. Hyderabad: Paras Medical Publisher; 2018 335,338

33 Pourghadiri M, Longhurst P, Watson TF. A new technique for the controlled removal of mottled enamel: measurement of enamel loss. Br Dent J 1998;184(5):239-241 